\title{
The effect of PPAR $\delta$ agonists (HS00098) on serum lipid profiles in diet-induced obese rhesus monkeys
}

\author{
Qihui Luo, Wen Zeng, Zhengli Chen", Anchun Cheng, Mingshu Wang, Yubo Shen, \\ Chunmei Zhu, Fengjun Bi
}

Key Laboratory of Animal Disease and Human Health of Sichuan Province, Ya'an, China

Email: "chzhli75@163.com

Received 10 May 2012; revised 14 June 2012; accepted 27 June 2012

\begin{abstract}
Aim: Activation of peroxisome proliferator-activated receptor $\delta$ (PPAR $\delta$ ) subtypes increases expression of genes involved in fatty acid transport and oxidation and alters adiposity in animal models of obesity and type-2 diabetes. We aim to explore the effects of peroxisome proliferator-activated receptor $\delta$ (PPAR $\delta$ ) subtypes on serum lipid profiles in obese rhesus monkey, especially evaluate the efficacy of investigational new drug (HS00098). Methods: First, a prototype of obese rhesus monkey was established by continuously feeding test animals a high fat diet for $\mathbf{2}$ months. Fifteen obese rhesus monkeys were randomly divided into 3 groups, and the 2 test groups were treated with GW 501516 and HS00098. The test groups were administered doses of $0.3 \mathrm{mg} / \mathrm{kg}$ for 1 month, then with $1 \mathrm{mg} / \mathrm{kg}$ for $1 \mathrm{month}$, and finally with $3 \mathrm{mg} / \mathrm{kg}$ for 1 month. The control group received placebo treatment. In each experiment, the body weight of each animal was measured and recorded initially and prior to changing the dose of the drug each month. The total cholesterol, blood glucose, triglyceride, high density lipoprotein cholesterol, low-density lipoprotein cholesterol, serum Apo-A1, Apo-B100 and insulin were tested. Results: The average body weight gain of the GW501516 and HS00098 groups was significantly lower than that of the control group. The group receiving the HS00098 treatment had a higher signifycant increase in high density lipoprotein and apo-A1 $(P<0.05)$ than the control monkeys, while the total cholesterol, triglycerides, low density lipoproteins, apo-B100, and insulin $(P<0.05$ or $P<0.01)$ were sig-

\footnotetext{
*The study was supported by the Program for Changjiang Scholars and Innovative Research Team in University (IRT0848), the Youth Foundation of Sichuan Province Sci \& Tech Bureau, China (08ZQ026-061), the National and Sichuan Province Innovation Funds for Moderate Scale Science and Technology Corporation (06C26215101716), Sichuan Province Basic Research Program (2008JY0100/ 2008JY0102) and Program for Key Disciplines Construction of Sichuan Province (SZD0418).

${ }^{\#}$ Corresponding author.
}

nificantly decreased. Compared with GW50-1516, the effects of HS00098 on serum lipid profiles in diet-induced obese rhesus monkeys are more obvious. Conclusion: These results suggested that the investigational drug (HSO0098) can effectively reduce body weight, blood lipid and blood sugar levels of diet-induced obese rhesus monkeys.

Keywords: PPAR $\delta$ Agonists; HS00098; Serum Lipid Profiles; Obese; Rhesus Monkey

\section{INTRODUCTION}

Obesity has risen to epidemic proportions worldwide and is one of the most visible, yet often neglected public health issues. It is now prevalent in virtually all age and socioeconomic groups in both developed and developing nations [1]. Obesity is a complex, multi-factorial condition produced by genetic, social, and psychological factors, the most significant being a high-fat diet and a sedentary life style. The health consequences of obesity range from increased risk of premature death to serious chronic conditions such as type 2 diabetes, dyslipidemia, atherosclerosis, hypertension, cardiovascular diseases, stroke, and certain forms of cancer [2-5]. Methods that reduce obesity through reductions in food intake or increased energy expenditure could serve as therapeutic options for the prevention of obesity and its comorbidities [6-8].

Peroxisome proliferator-activated receptors (PPARs) are ligand-activated transcription factors that belong to the superfamily of nuclear receptors [9]. Three subtypes, designated PPAR $\alpha$ (NR1C1), PPAR $\delta$ (NR1C2), and PPAR $\gamma$ (NR1C3) have been identified as endogenous ligands that include fatty acids and fatty acid metabolites. PPARs form heterodimers with retinoid X receptors (RXRs) and bind to the hexanucleotidic PPAR responsive element (PPRE), thereby regulating the expression of target genes involved in lipid and carbohydrate metabolism. PPARs are found in species ranging from 
Xenopus to humans [9] with each receptor having a distinct tissue expression profile. PPAR $\alpha$ is expressed mainly in the liver, heart, and muscle. PPAR $\gamma$ is expressed predominantly in white and brown adipose tissue and is important in the regulation and control of adipocyte development and function [10]. PPAR $\delta$ has a broad pattern of distribution and is expressed in many tissues, including muscle and kidney [11]. Recent work has suggested that PPAR $\delta$ is involved in overall energy regulation and fatty acid oxidation in muscle. Activation of PPAR $\delta$ has also been shown to increase high-density lipoprotein cholesterol (HDL-c) in diabetic $\mathrm{db} / \mathrm{db}$ mice and obese rhesus monkeys [12]. Studies by Wang et al. [13] suggest that the overexpression of PPAR $\delta$ in adipose tissue protects against diet-induced obesity in mice and treatment with a PPAR $\delta$ selective agonist inhibits weight gain without effects on food intake in fat-fed mice [14]. A number of studies have described the effect of individual PPAR agonists in a variety of animal models or experimental paradigms [12,15-17].

This study provides a systematic 3-month evaluation of PPAR $\delta$ agonist (GW501516, developed by Glaxo Smith Kline) and PPAR $\delta$ agonist (HS00098) in a single model of chronic diet-induced obesity. This report evaluates the efficacy of the investigational drug (HS00098) on serum lipid profiles in obese rhesus monkeys.

\section{MATERIALS AND METHODS}

\subsection{Equipment and Reagent}

The Medonic CA620 fully automatic hematology analyzer, the ACL100 coagulation analyzer, the Beckman Synchron CX4 Pro clinical chemistry analyzer, the Bio-Rad enzyme immunoassay analyzer, monkey Apo-A1, Apo-B100, and Insulin ELISA kits (Uscnlife Science \& Technology CO., LTD, E0604Mo, E0603Mo, E0448Mo) were used in this experiment. GW501516 capsules (Lot Number: 0701) and HS00098 capsules (Lot Number: 20070412) were provided by Zhejiang Hisun Pharmaceutical Co. Ltd. The chemical structural formula of HS00098 is shown in Figure 1.

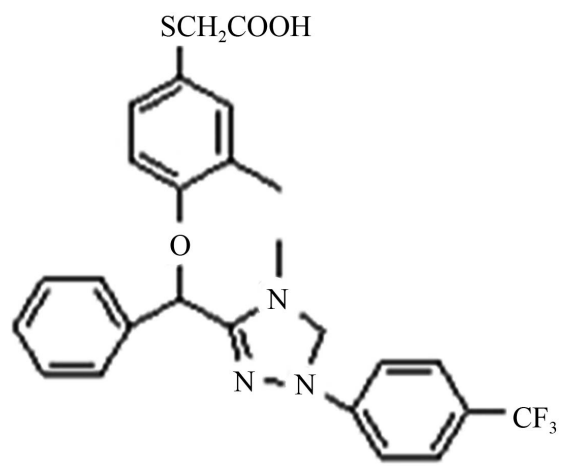

Figure 1. The chemical structural formula of HS00098.

\subsection{Animal Selection and High Fat Diet}

The experimental procedures were in accordance with the Guidance Suggestions for the Care and Use of Laboratory Animals, the Ministry of Science and Technology of China [18]. Animals were housed at $22^{\circ} \mathrm{C}$ and $50 \%$ relative humidity with a 12 -hour light and dark cycle.

Fifty 7-13 year old male rhesus monkeys with a body mass index (BMI) greater than 35, weighing $9 \mathrm{~kg}$ or more, were obtained from the National (Sichuan) Experimental Rhesus Monkey Resources Base (Certificate Number: $22)$. The animals were quarantined and domesticated for 30 days before the experiment. Animal quarantine procedures included physical examinations, Mycobacterium tuberculosis tests (twice), and tests for parasites, Salmonella, Shigella, and B virus. Only monkeys that passed the quarantine and met the national criteria were used for this study. Monkeys were kept under controlled conditions of temperature $\left(20^{\circ} \mathrm{C}-28^{\circ} \mathrm{C}\right)$ and humidity $(40 \%$ $70 \%$ ). A 12-h day and night cycle was maintained in the animal house. The monkeys were housed one per standard stainless steel cage with free food and water. A high fat diet (main ingredients for $18 \%$ protein, $60 \%$ carbohydrate, $8 \%$ fat) was provided to each animal (available ad libitum) in the morning, and an equally nutritious apple or vegetable was provided around $4 \mathrm{pm}$.

\subsection{Establishment of Obese Rhesus Monkeys}

The monkeys were continuously fed with a high fat diet for 2 months. On the final day of each month, a terminal blood sample $(1 \mathrm{~mL})$ was obtained via the femoral vein of the posterior limb. Routine blood tests mainly included total cholesterol (T-CHO), glucose, triglyceride (TG), high density lipoprotein cholesterol (HDLc), low density lipoprotein cholesterol (LDLc) [19-22]. At the same time, the level of serum insulin was tested by using the monkey insulin ELISA kit. When a stable increase of TC, TG, LDLc levels and a decrease in HDLc was accompanied by increased blood glucose levels and insulin levels for 2 consecutive tests, the models of obese animal were considered a success.

\subsection{Grouping and Administration of Obese Rhesus Monkeys}

Fifteen obese rhesus monkeys were selected according to their relatively approximate body weight and stable serum TC, TG, LDLc levels, and randomly divided into 3 groups, each with five animals. One group of animals was dosed with PPAR $\delta$ agonist (GW501516 capsule) and another group was administered the investigational drug (HS00098 capsule) for 3 months, and the control group was administered oral placebo. All animals were fed $200 \mathrm{~g}$ of food in a high-fat diet daily. The GW501516 animals (numbers: 0141, 0375, 0997, 1003, 0047) and 
HS00098 group animals (numbers: 0851, 0483, 0869, $0379,1029)$ were treatment with tris-dosage, first were treated with $0.3 \mathrm{mg} / \mathrm{kg} \mathrm{G}$ for 1 month, then treated with 1 $\mathrm{mg} / \mathrm{kg} \mathrm{GW} 501516$ for 1 month, finally treated with 3 $\mathrm{mg} / \mathrm{kg}$ GW501516 for 1 month, and one week withdrawal period between the two doses. At the end of each month after administration, test related data. The control group animals (numbers: 1011, 0901, 0099, 0441, 0095) were simulated oral administration and the other treatment like the above.

\subsection{Assessment during the Experiment}

In each experiment, the body weight (BW) of each animal was measured and recorded initially, and then after the first, second, and third month throughout the experiment.

Hematology and biochemical analyses, including total cholesterol (T-CHO), blood glucose (BG), triglyceride (TG), high density lipoprotein cholesterol (HDLc), and low density lipoprotein cholesterol (LDLc), were performed before and after the administration at the end of each month.

Before the administration and at the end of each month after each administration, the levels of serum Apo-A1, Apo-B100 and insulin were tested using the monkey Apo-A1, Apo-B100, and the Insulin ELISA kit to monitor the levels of serum lipids and serum glucose during the drug trial.

\subsection{Data Statistical Analysis}

All data are expressed as the value of individual data and mean (SD). Each individual's data was analyzed for changes after their treatment with the experimental drugs (including T-CHO, BG, TG, HDLc, LDLc, Apo-A1, Apo-B100 and insulin). Then the differences between the groups were analyzed using the two-way analysis of variance with repeated measures model (ANOVA) followed by Dunnett's post hoc test. The values were considered to be significant when a value of $\mathrm{P}<0.05$ was achieved.

\section{RESULTS}

\subsection{Body Weight Changes after Treatment with HS00098 and GW501516}

According to Table 1, after successive treatment for 3 months, the results were as follows: the mean weight gain of the GW501516 and HS00098 groups was significantly lower than that of the control group, and the mean weight gain of the HS00098 group was lower than that of the GW501516 group. According to the individual weight data, 1 monkey lost weight with GW 501516 and 3 monkeys lost weight with HS00098, but 4 monkeys gained weight in the control group. However, the food intake of the HS00098 animals decreased, whereas the food intake for the GW501516 animals changed little.

Table 1. Individual data of body weight changes in obese rhesus monkeys after treatment with HS00098 and GW501516 (kg).

\begin{tabular}{|c|c|c|c|c|c|c|}
\hline Group & Pre-administration & $\begin{array}{c}0.3 \mathrm{mg} / \mathrm{kg} \\
\text { (first month) }\end{array}$ & $\begin{array}{c}1 \mathrm{mg} / \mathrm{kg} \\
\text { (second month) }\end{array}$ & $\begin{array}{c}3 \mathrm{mg} / \mathrm{kg} \\
\text { (third month) }\end{array}$ & $\begin{array}{c}\text { Value of third month } \\
\text { subtract } \\
\text { pre-administration }\end{array}$ & $\begin{array}{c}\text { Mean } \\
\text { weight gain }\end{array}$ \\
\hline \multirow{5}{*}{ GW501516 } & 8.70 & 8.50 & 9.10 & 9.00 & 0.30 & \multirow{5}{*}{-0.08} \\
\hline & 8.40 & 8.70 & 8.50 & 8.80 & 0.40 & \\
\hline & 11.60 & 11.40 & 12.00 & 12.00 & 0.40 & \\
\hline & 13.20 & 12.50 & 12.50 & 11.80 & $(1.40)$ & \\
\hline & 8.20 & 7.70 & 8.30 & 8.40 & 0.20 & \\
\hline \multirow{5}{*}{ HS00098 } & 7.40 & 6.70 & 7.20 & 7.10 & $(0.30)$ & \multirow{5}{*}{-0.18} \\
\hline & 9.60 & 9.40 & 9.60 & 9.40 & $(0.20)$ & \\
\hline & 7.20 & 6.80 & 7.50 & 7.20 & 0.00 & \\
\hline & 11.20 & 10.80 & 11.90 & 12.20 & 1.00 & \\
\hline & 13.00 & 12.50 & 12.80 & 11.60 & $(1.40)$ & \\
\hline \multirow{5}{*}{ Control group } & 13.90 & 11.80 & 13.50 & 13.70 & $(0.20)$ & \multirow{5}{*}{0.56} \\
\hline & 8.20 & 8.00 & 8.70 & 9.20 & 1.00 & \\
\hline & 9.30 & 8.90 & 9.10 & 9.70 & 0.40 & \\
\hline & 10.10 & 10.10 & 10.80 & 10.80 & 0.70 & \\
\hline & 7.60 & 7.50 & 8.00 & 8.50 & 0.90 & \\
\hline
\end{tabular}

The values in brackets are the decreased values. 


\subsection{Effects of PPAR $\delta$ on the Serum Lipid Profiles}

According to Tables 2-4 and Figures 2(a)-2(d), 2(g), 2(h), after 3 consecutive months of treatment, the results were as follows: The T-CHO values in the GW501516 and HS00098 groups were lower than that in the control group, but it was not considered significant $(\mathrm{P}>0.05)$. The T-CHO value for the HS00098 group was lower than the value for the GW501516 group. Compared to the control and GW501516 groups, the HDLc, Apo-A1 and insulin levels of HS00098 group were significantly increased, while the level of LDLc and Apo-B100 were significantly decreased. The TG levels of the GW501516 and HS00098 groups were obviously lower than that of the control group, especially when treated with $3 \mathrm{mg} / \mathrm{kg}$. According to the data analysis (Tables 2-4), the general trends were as follows: After 3 months of treatment, the animals with rising HDLc levels had significantly increased as the dosage increased. At the same time, the animals with falling T-CHO and LDLc levels decreased further as the dosage increased. The increasing/decreasing trends were more pronounced with the HS00098 animals than with the GW501516 animals at the same dosage.

\subsection{Effects of PPAR $\delta$ on BG and Insulin}

According to Figures 2(e), 2(f), after 3 months of treat- ment, the insulin levels showed an increasing trend. The insulin level of GW501516 group gradually increased to 0.3 at the $1 \mathrm{mg} / \mathrm{kg}$ dosage and slightly decreased at 3 $\mathrm{mg} / \mathrm{kg}$ dosage, while that of HS00098 group increased significantly at the $0.3 \mathrm{mg} / \mathrm{kg}$ dosage and then decreased. At the same time, the insulin level of control group remained higher as time went on and was significantly higher than the other 2 groups. It was observed that the rate of increase was similar in both GW501516 and HS00098 groups. In addition, the BG level changed little in each group and dosage.

\section{DISCUSSION}

Recently, the antidiabetic GLP-1 agonist exenatide (Byetta) was shown to significantly reduce mean body weight $(-4.7 \%)$ after 2 years of treatment [23]. In addition, recent studies have shown that peroxisome proliferator-activated receptor (PPAR) delta agonists could induce weight loss by increasing energy expenditure and fatty acid oxidation [13]. In fact, PPAR $\delta$ agonism either alone or in combination with agonisms of PPAR $\alpha$ and/or PPAR $\gamma$ could not only induce body weight loss but could also potentially improve other metabolic parameters, including insulin sensitivity and lipid profiles. Our results discovered that the mean weight gain of the GW501516 and HS00098 groups was significantly lower than that of the control group, thereby suggesting that

Table 2. Individual data of cholesterol changes in obese rhesus monkeys after treatment with HS00098 and GW501516 (unit: $\mathrm{mol} / \mathrm{L})$.

\begin{tabular}{|c|c|c|c|c|c|c|c|c|c|c|c|c|c|}
\hline \multirow[t]{2}{*}{ Group } & \multirow[t]{2}{*}{$\begin{array}{c}\text { Animal } \\
\text { numbers }\end{array}$} & \multirow[t]{2}{*}{ Pre-administration } & \multirow[t]{2}{*}{$\begin{array}{c}0.3 \mathrm{mg} / \mathrm{kg} \\
\text { (first } \\
\text { month) }\end{array}$} & \multirow[t]{2}{*}{$\begin{array}{l}1 \mathrm{mg} / \mathrm{kg} \\
\text { (second } \\
\text { month) }\end{array}$} & \multirow[t]{2}{*}{$\begin{array}{l}3 \mathrm{mg} / \mathrm{kg} \\
\text { (third } \\
\text { month) }\end{array}$} & \multicolumn{2}{|c|}{$\begin{array}{c}\text { Change in the } \\
\text { third month } \\
\text { subtract } \\
\text { pre-administration }\end{array}$} & \multicolumn{2}{|c|}{$\begin{array}{c}\text { Change in the } \\
\text { third month } \\
\text { subtract first } \\
\text { month }\end{array}$} & \multicolumn{2}{|c|}{$\begin{array}{l}\text { Change in the } \\
\text { second month } \\
\text { subtract first } \\
\text { month }\end{array}$} & \multicolumn{2}{|c|}{$\begin{array}{l}\text { Change in the } \\
\text { first month } \\
\text { subtract } \\
\text { pre-administration }\end{array}$} \\
\hline & & & & & & $\begin{array}{c}\text { Change } \\
\text { value }\end{array}$ & $\begin{array}{l}\text { Change } \\
\text { rate }(\%)\end{array}$ & $\begin{array}{l}\text { Change } \\
\text { value }\end{array}$ & $\begin{array}{l}\text { Change } \\
\text { rate }(\%)\end{array}$ & $\begin{array}{l}\text { Change } \\
\text { value }\end{array}$ & $\begin{array}{l}\text { Change } \\
\text { rate (\%) }\end{array}$ & $\begin{array}{l}\text { Change } \\
\text { value }\end{array}$ & $\begin{array}{l}\text { Change } \\
\text { rate }(\%)\end{array}$ \\
\hline \multirow{5}{*}{ GW501516 } & 0141 & 14.62 & 13.90 & 10.57 & 8.59 & 6.03 & 41.24 & 1.98 & 18.73 & 3.33 & 23.96 & 0.72 & 4.92 \\
\hline & 0375 & 13.61 & 11.46 & 10.83 & 10.86 & 2.75 & 20.21 & $(0.03)$ & $(0.28)$ & 0.63 & 5.50 & 2.15 & 15.80 \\
\hline & 0997 & 12.50 & 9.94 & 11.53 & 11.83 & 0.67 & 5.36 & $(0.30)$ & $(2.60)$ & $(1.59)$ & $(16.00)$ & 2.56 & 20.48 \\
\hline & 1003 & 13.43 & 11.43 & 12.78 & 12.54 & 0.89 & 6.63 & 0.24 & 1.88 & $(1.35)$ & $(11.81)$ & 2.00 & 14.89 \\
\hline & 0047 & 21.30 & 18.75 & 17.90 & 19.97 & 1.33 & 6.24 & $(2.07)$ & $(11.56)$ & 0.85 & 4.53 & 2.55 & 11.97 \\
\hline \multirow{5}{*}{ HS00098 } & 0851 & 16.17 & 12.92 & 11.84 & 9.51 & 6.66 & 41.19 & 2.33 & 19.68 & 1.08 & 8.36 & 5.25 & 20.10 \\
\hline & 0483 & 16.92 & 12.57 & 9.13 & 7.50 & 9.42 & 55.67 & 1.63 & 17.85 & 3.44 & 27.37 & 4.35 & 25.71 \\
\hline & 0869 & 14.55 & 11.14 & 9.13 & 6.44 & 8.11 & 55.74 & 2.69 & 29.46 & 2.01 & 18.04 & 3.41 & 23.44 \\
\hline & 0379 & 14.20 & 12.75 & 11.02 & 11.56 & 2.64 & 18.59 & $(0.54)$ & $(4.90)$ & 1.73 & 13.57 & 1.45 & 10.21 \\
\hline & 1029 & 12.92 & 11.54 & 10.17 & 7.40 & 5.52 & 42.72 & 2.77 & 27.24 & 1.37 & 11.87 & 1.38 & 10.68 \\
\hline \multirow{5}{*}{ Control group } & 1011 & 11.84 & 8.48 & 9.09 & 9.81 & 2.03 & 17.15 & $(0.72)$ & (7.92) & $(0.61)$ & (7.19) & 3.36 & 28.38 \\
\hline & 0901 & 12.54 & 10.12 & 9.54 & 9.96 & 2.58 & 20.57 & $(0.42)$ & $(4.40)$ & 0.58 & 5.73 & 2.42 & 19.30 \\
\hline & 0441 & 14.70 & 15.98 & 13.27 & 15.38 & $(0.68)$ & $(4.63)$ & $(2.11)$ & $(15.90)$ & 2.71 & 16.96 & $(1.28)$ & $(8.71)$ \\
\hline & 0099 & 13.39 & 11.86 & 11.82 & 13.15 & 0.24 & 1.79 & $(1.33)$ & $(11.25)$ & 0.04 & 0.34 & 1.53 & 11.43 \\
\hline & 0095 & 16.93 & 16.92 & 15.16 & 16.72 & 0.21 & 1.24 & $(1.56)$ & $(10.29)$ & 1.76 & 10.40 & 0.01 & 0.06 \\
\hline
\end{tabular}

The normal reference value of serum cholesterol of 6-10 year-old male rhesus monkeys in our laboratory: $3.12 \pm 0.64$ mol/L ( $\mathrm{n}=100$ ); the values in brackets are the increased value and rate. 
Table 3. Individual data of HDL changes in obese rhesus monkeys after treatment with HS00098 and GW501516 (unit: mol/L).

\begin{tabular}{|c|c|c|c|c|c|c|c|c|c|c|c|c|c|}
\hline \multirow[t]{2}{*}{ Group } & \multirow[t]{2}{*}{$\begin{array}{l}\text { Animal } \\
\text { numbers }\end{array}$} & \multirow[t]{2}{*}{ Pre-administration } & \multirow{2}{*}{$\begin{array}{c}0.3 \mathrm{mg} / \mathrm{kg} \\
\text { (first } \\
\text { month) }\end{array}$} & \multirow{2}{*}{$\begin{array}{l}1 \mathrm{mg} / \mathrm{kg} \\
\text { (second } \\
\text { month) }\end{array}$} & \multirow{2}{*}{$\begin{array}{c}3 \mathrm{mg} / \mathrm{kg} \\
\text { (third } \\
\text { month) }\end{array}$} & \multicolumn{2}{|c|}{$\begin{array}{l}\text { Change in the } \\
\text { third month } \\
\text { subtract } \\
\text { pre-administration }\end{array}$} & \multicolumn{2}{|c|}{$\begin{array}{l}\text { Change in the } \\
\text { third month } \\
\text { subtract first } \\
\text { month }\end{array}$} & \multicolumn{2}{|c|}{$\begin{array}{l}\text { Change in the } \\
\text { second month } \\
\text { subtract first } \\
\text { month }\end{array}$} & \multicolumn{2}{|c|}{$\begin{array}{l}\text { Change in the } \\
\text { first month } \\
\text { subtract } \\
\text { pre-administration }\end{array}$} \\
\hline & & & & & & $\begin{array}{l}\text { Change } \\
\text { value }\end{array}$ & $\begin{array}{l}\text { Change } \\
\text { rate }(\%)\end{array}$ & $\begin{array}{l}\text { Change } \\
\text { value }\end{array}$ & $\begin{array}{l}\text { Change } \\
\text { rate }(\%)\end{array}$ & $\begin{array}{l}\text { Change } \\
\text { value }\end{array}$ & $\begin{array}{l}\text { Change } \\
\text { rate (\%) }\end{array}$ & $\begin{array}{l}\text { Change } \\
\text { value }\end{array}$ & $\begin{array}{l}\text { Change } \\
\text { rate }(\%)\end{array}$ \\
\hline \multirow{5}{*}{ GW501516 } & 0141 & 1.390 & 1.260 & 1.450 & 1.760 & 0.370 & 26.619 & 0.310 & 21.379 & 0.190 & 15.079 & $(0.130)$ & $(9.35)$ \\
\hline & 0375 & 1.720 & 2.090 & 1.920 & 2.860 & 1.140 & 66.279 & 0.940 & 48.958 & $(0.170)$ & $(8.134)$ & 0.370 & 21.51 \\
\hline & 0997 & 1.890 & 1.840 & 1.780 & 1.830 & $(0.060)$ & $(3.175)$ & 0.050 & 2.809 & $(0.060)$ & $(3.261)$ & $(0.050)$ & $(2.65)$ \\
\hline & 1003 & 2.140 & 1.910 & 2.210 & 2.000 & $(0.140)$ & $(6.542)$ & $(0.210)$ & $(9.502)$ & 0.300 & 15.707 & $(0.230)$ & (10.75) \\
\hline & 0047 & 1.570 & 1.340 & 1.260 & 1.460 & $(0.110)$ & $(7.006)$ & 0.200 & 15.873 & $(0.080)$ & $(5.970)$ & $(0.230)$ & (14.65) \\
\hline \multirow{5}{*}{ HS00098 } & 0851 & 1.160 & 1.160 & 1.500 & 1.830 & 0.670 & 57.759 & 0.330 & 22.000 & 0.340 & 29.310 & 0.000 & 0.00 \\
\hline & 0483 & 0.950 & 1.100 & 1.480 & 1.870 & 0.920 & 96.842 & 0.390 & 26.351 & 0.380 & 34.545 & 0.150 & 15.79 \\
\hline & 0869 & 1.440 & 1.550 & 2.380 & 2.570 & 1.130 & 78.472 & 0.190 & 7.983 & 0.830 & 53.548 & 0.110 & 7.64 \\
\hline & 0379 & 1.010 & 1.050 & 1.360 & 1.720 & 0.710 & 70.297 & 0.360 & 26.471 & 0.310 & 29.524 & 0.040 & 3.96 \\
\hline & 1029 & 1.020 & 1.060 & 1.130 & 1.210 & 0.190 & 18.627 & 0.080 & 7.080 & 0.070 & 6.604 & 0.040 & 3.92 \\
\hline \multirow{5}{*}{ Control group } & 1011 & 1.770 & 1.860 & 1.920 & 1.790 & 0.020 & 1.130 & $(0.130)$ & $(6.771)$ & 0.060 & 3.226 & 0.090 & 5.08 \\
\hline & 0901 & 0.800 & 0.880 & 0.920 & 1.160 & 0.360 & 45.000 & 0.240 & 26.087 & 0.040 & 4.545 & 0.080 & 10.00 \\
\hline & 0441 & 1.040 & 0.960 & 1.210 & 1.260 & 0.220 & 21.154 & 0.050 & 4.132 & 0.250 & 26.042 & $(0.080)$ & $(7.69)$ \\
\hline & 0099 & 1.230 & 1.040 & 1.120 & 1.200 & $(0.030)$ & $(2.439)$ & 0.080 & 7.143 & 0.080 & 7.692 & $(0.190)$ & $(15.45)$ \\
\hline & 0095 & 0.900 & 1.440 & 1.660 & 0.920 & 0.020 & 2.222 & $(0.740)$ & (44.578) & 0.220 & 15.278 & 0.540 & 60.00 \\
\hline
\end{tabular}

The normal reference value of HDL of 6-10 year-old male rhesus monkeys in our laboratory: $1.92 \pm 0.34 \mathrm{~mol} / \mathrm{L}(\mathrm{n}=100)$; the values in brackets are the decreased value and rate.

Table 4. individual data of LDL changes in obese rhesus monkeys after treatment with HS00098 and GW501516 (unit: mol/L).

\begin{tabular}{|c|c|c|c|c|c|c|c|c|c|c|c|c|c|}
\hline \multirow[t]{2}{*}{ Group } & \multirow[t]{2}{*}{$\begin{array}{c}\text { Animal } \\
\text { numbers }\end{array}$} & \multirow[t]{2}{*}{ Pre-administration } & \multirow[t]{2}{*}{$\begin{array}{l}0.3 \mathrm{mg} / \mathrm{kg} \\
\text { (first } \\
\text { month) }\end{array}$} & \multirow[t]{2}{*}{$\begin{array}{l}1 \mathrm{mg} / \mathrm{kg} \\
\text { (second } \\
\text { month) }\end{array}$} & \multirow[t]{2}{*}{$\begin{array}{l}3 \mathrm{mg} / \mathrm{kg} \\
\text { (third } \\
\text { month) }\end{array}$} & \multicolumn{2}{|c|}{$\begin{array}{l}\text { Changes in the } \\
\text { third month } \\
\text { subtract } \\
\text { pre-administration }\end{array}$} & \multicolumn{2}{|c|}{$\begin{array}{l}\text { Changes in the } \\
\text { third month } \\
\text { subtract first } \\
\text { month }\end{array}$} & \multicolumn{2}{|c|}{$\begin{array}{l}\text { Changes in the } \\
\text { second month } \\
\text { subtract first } \\
\text { month }\end{array}$} & \multicolumn{2}{|c|}{$\begin{array}{l}\text { Changes in the } \\
\text { first month } \\
\text { subtract } \\
\text { pre-administration }\end{array}$} \\
\hline & & & & & & $\begin{array}{c}\text { Change } \\
\text { value }\end{array}$ & $\begin{array}{l}\text { Change } \\
\text { rate }(\%)\end{array}$ & $\begin{array}{l}\text { Change } \\
\text { value }\end{array}$ & $\begin{array}{l}\text { Change } \\
\text { rate (\%) }\end{array}$ & $\begin{array}{c}\text { Change } \\
\text { value }\end{array}$ & $\begin{array}{l}\text { Change } \\
\text { rate }(\%)\end{array}$ & $\begin{array}{l}\text { Change } \\
\text { value }\end{array}$ & $\begin{array}{l}\text { Change } \\
\text { rate }(\%)\end{array}$ \\
\hline \multirow{5}{*}{ GW501516 } & 0141 & 7.720 & 7.620 & 8.010 & 6.210 & 1.510 & 19.560 & 1.800 & 22.472 & $(0.390)$ & $(5.118)$ & 0.100 & 1.295 \\
\hline & 0375 & 6.750 & 6.420 & 7.120 & 6.020 & 0.730 & 10.815 & 1.100 & 15.449 & $(0.700)$ & $(10.903)$ & 0.330 & 4.889 \\
\hline & 0997 & 6.960 & 6.020 & 10.060 & 9.910 & $(2.950)$ & (42.385) & 0.150 & 1.491 & $(4.040)$ & $(67.110)$ & 0.940 & 13.506 \\
\hline & 1003 & 7.790 & 6.980 & 11.040 & 9.470 & $(1.680)$ & (21.566) & 1.570 & 14.221 & $(4.060)$ & $(58.166)$ & 0.810 & 10.398 \\
\hline & 0047 & 10.210 & 9.250 & 13.190 & 14.980 & $(4.770)$ & (46.719) & $(1.790)$ & $(13.571)$ & $(3.940)$ & $(42.595)$ & 0.960 & 9.403 \\
\hline \multirow{5}{*}{ HS00098 } & 0851 & 11.500 & 10.010 & 10.990 & 6.890 & 4.610 & 40.087 & 4.100 & 37.307 & $(0.980)$ & $(9.790)$ & 1.490 & 12.957 \\
\hline & 0483 & 10.000 & 8.840 & 8.220 & 5.560 & 4.440 & 44.400 & 2.660 & 32.360 & 0.620 & 7.014 & 1.160 & 11.600 \\
\hline & 0869 & 8.480 & 6.860 & 6.770 & 3.750 & 4.730 & 55.778 & 3.020 & 44.609 & 0.090 & 1.312 & 1.620 & 19.104 \\
\hline & 0379 & 8.030 & 7.090 & 9.570 & 9.540 & $(1.510)$ & (18.804) & 0.030 & 0.313 & $(2.480)$ & (34.979) & 0.940 & 11.706 \\
\hline & 1029 & 8.350 & 7.850 & 9.840 & 5.780 & 2.570 & 30.778 & 4.060 & 41.260 & (1.990) & $(25.350)$ & 0.500 & 5.988 \\
\hline \multirow{5}{*}{ Control group } & 1011 & 7.250 & 4.970 & 7.380 & 6.750 & 0.500 & 6.897 & 0.630 & 8.537 & $(2.410)$ & $(48.491)$ & 2.280 & 31.448 \\
\hline & 0901 & 7.650 & 6.740 & 8.860 & 7.290 & 0.360 & 4.706 & 1.570 & 17.720 & $(2.120)$ & (31.454) & 0.910 & 11.895 \\
\hline & 0441 & 8.630 & 7.850 & 5.820 & 4.680 & 3.950 & 45.771 & 1.140 & 19.588 & 2.030 & 25.860 & 0.780 & 9.038 \\
\hline & 0099 & 9.450 & 10.520 & 11.460 & 12.970 & $(3.520)$ & (37.249) & $(1.510)$ & (13.176) & $(0.940)$ & $(8.935)$ & $(1.070)$ & (11.323) \\
\hline & 0095 & 6.030 & 5.420 & 2.790 & 8.550 & $(2.520)$ & (41.791) & $(5.760)$ & (206.452) & 2.630 & 48.524 & 0.610 & 10.116 \\
\hline
\end{tabular}

The normal reference value of LDL of 6-10 year-old male rhesus monkeys in our laboratory: $2.34 \pm 0.54 \mathrm{~mol} / \mathrm{L}(\mathrm{n}=100)$; the values in brackets are the increased value and rate. 


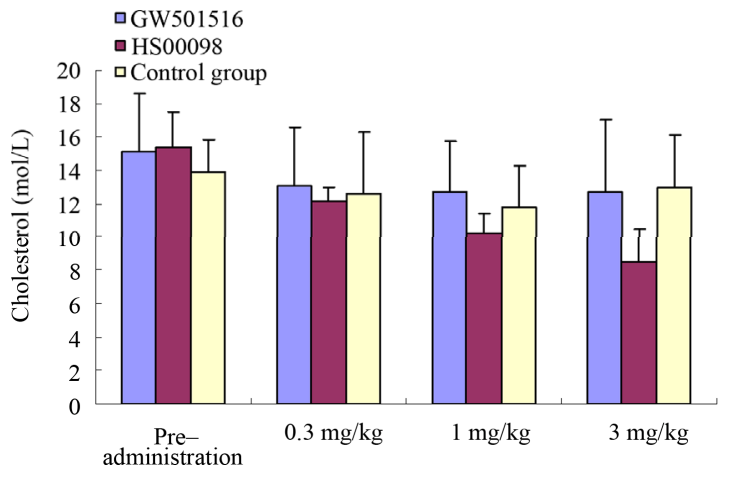

(a)

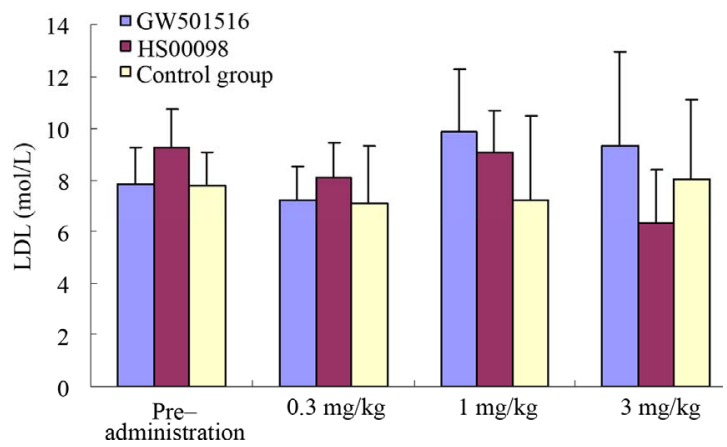

(c)

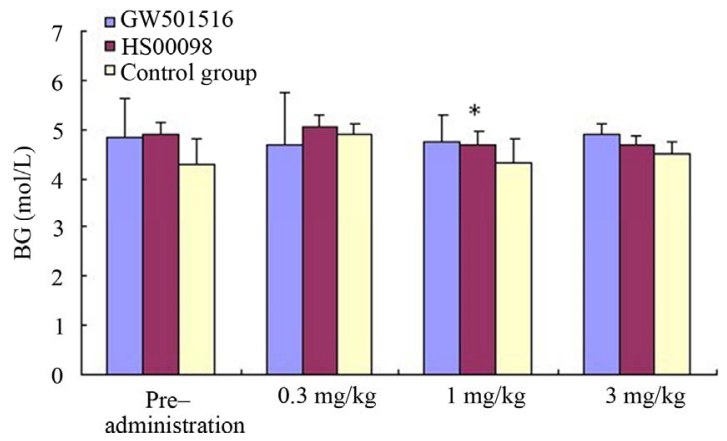

(e)

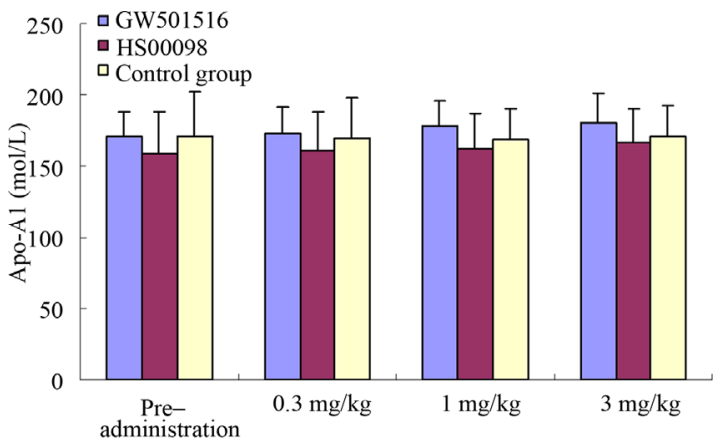

(g)

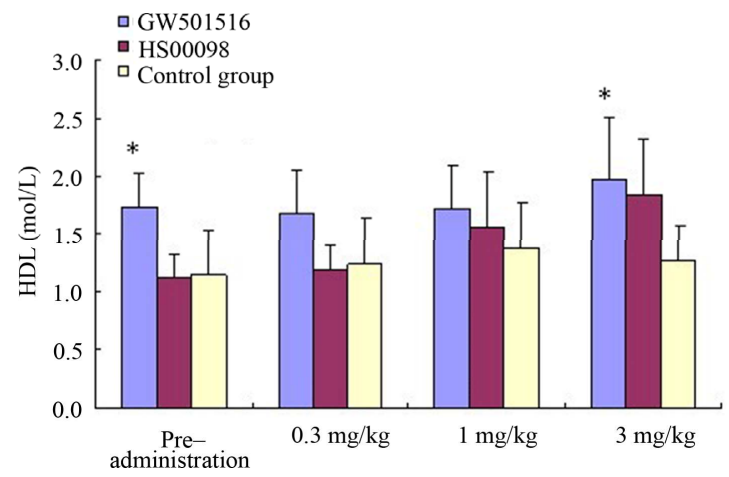

(b)

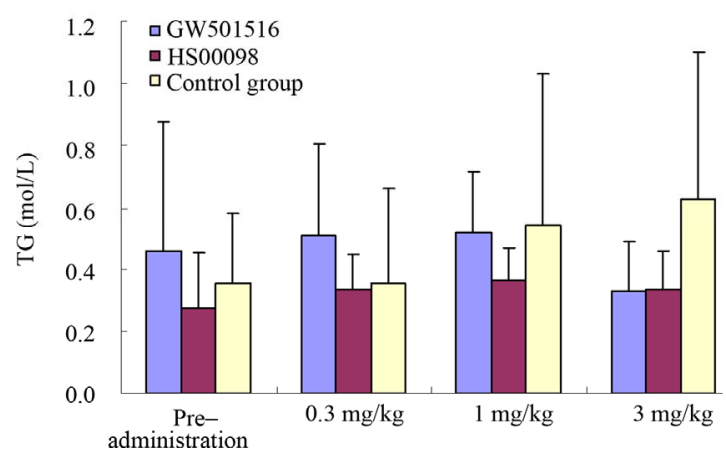

(d)

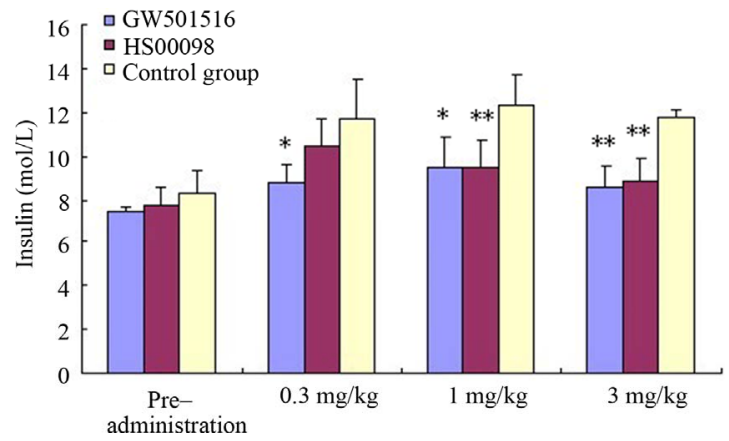

(f)

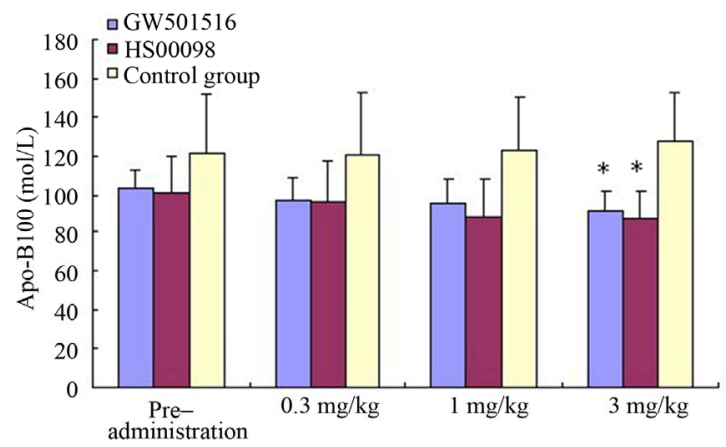

(h)

Figure 2. Effect of treatment with selective PPAR $\delta$ agonists (GW501516 and HS00098) on serum cholesterol (CHO) (a); High density lipoprotein cholesterol (HDLc) (b); Low density lipoprotein cholesterol (LDLc) (c); Triglyceride (TG) (d); Blood glucose (BG) (e); Insulin (f); Apo-A1 (g); and Apo-B100 (h) in diet-induced obese rhesus monkeys. All data are expressed as mean (SD). Each dose was administered for 1 month. Initially and at the end of each month after drug treatment, the data were compared with the control group and analyzed by ANOVA with repeated measures followed by Dunnett's post hoc test. The values were considered to be significant $\left(^{*}\right)$ when a value of $\mathrm{P}<0.05$ was achieved. $\mathrm{N}=5$ animals/group. 
both drugs could induce weight loss. Although the weight gain of the HS00098 subjects was lower than that of the GW501516 group, it is difficult to determine the cause considering the decreased food intake of the HS00098 animals.

Studies have revealed that PPAR $\delta$ controls an array of metabolic genes involved in glucose homeostasis and fatty acid synthesis/storage, and mobilization and catabolism in a tissue-specific manner. A number of studies have also shown that PPAR $\delta$ agonists regulate food intake, body weight, insulin sensitivity, and adiposity [8,24-30]. Transgenic mice, in which constitutively active PPAR $\delta$ is expressed in muscle, are highly resistant to high-fat, diet-induced obesity [13]. Several synthetic ligands, namely GW501516, GW7042 and L165041, have also been developed, each exhibiting different efficacies in ameliorating symptoms of metabolic disorders [12,29,31,32]. GW501516, a selective PPAR $\delta$ agonist, promotes fatty acid oxidation and utilization, and reduces lipid accumulation in adipocytes, skeletal muscle, and in the liver in diet-induced obese ob/ob [30], and db/db mice [29]. In fact, GW501516, a high affinity synthetic agonist, has been shown to reduce weight gain and decrease circulating TGs in mice fed a high fat diet or ob/ob mice $[14,33]$. The results from the GW501516 group in this study and also in a similar report proved that HS00098 (an investigational drug and a PPAR $\delta$ agonist) had an even stronger effect than the GW501516.

In humans, lipid homeostasis is a delicate balance among dietary intake, de novo synthesis, and catabolism. The increased incidence of cardiovascular disease in Westernized nations has been linked to dyslipidemias associated with changes in the fat content of the diet [34]. Obesity, insulin resistance, and hypertension are comorbidities with these lipid disorders; these together are known as the metabolic syndrome $\mathrm{X}$ [35]. Individuals with this condition have high serum triglycerides and abnormally low levels of HDLc $[35,36]$. This lipid profile is accompanied by an increase in the proportion of small-dense LDL particles, which tend to accumulate in the arterial wall leading to the formation of atherosclerotic cholesterol-laden foam cells [37]. HDL plays a protective role through the process of reverse cholesterol transport whereby cholesterol is removed from the peripheral cells, including the macrophage-derived foam cells, and re- turned to the liver [38]. Agents that raise the levels of HDL through reverse cholesterol transport could provide a new therapeutic option for the prevention of atherosclerotic cardiovascular disease [2]. Our data showed that both GW501516 and HS00098 reduced circulating TG, T-CHO, Apo-B100, and LDLc and prevented the decline of HDLc, apoA-1, and insulin levels, thereby suggesting that GW 501516 and HS00098 regulated the lipid homeostasis. The data from the test group
HS00098 were more pronounced than those from the test group GW501516, thereby suggesting that the effect of HS00098 on serum profiles was stronger than the effect of GW501516. This implied that HS00098 played an important role in ameliorating the serum lipid profiles of high-fat diet-induced obese rhesus monkeys. Collectively, this data suggested that HS00098 and GW501516 increased fat combustion and may provide a means to regulate adiposity.

The effect of GW501516 on glucose homeostasis has been studied in several mouse models of insulin resistance/ type II diabetes. In C57BL/6 mice fed a high fat diet, coadministration of this PPAR $\delta$ agonist at $3 \mathrm{mg} \cdot \mathrm{kg}^{-1} \cdot \mathrm{day}^{-1}$ for 2 months increased the metabolic rate, reduced fatty liver, and decreased lipid accumulation and increased mitochondrial biogenesis in muscle. The circulating insulin levels also declined, whereas the improvement in glucose tolerance and insulin sensitivity determined by the glucose and insulin tolerant test (GTT and ITT) was moderate [33]. The effect appeared to be dose-dependent at $10 \mathrm{mg} \cdot \mathrm{kg}^{-1} \cdot \mathrm{day}^{-1}$, wherein the ability of GW501516 to lower blood glucose levels and enhance glucose tolerance became apparent [14]. Interestingly, in addition to improving glucose homeostasis, GW501516 treatment normalized pancreatic islet hypertrophy and increased glucose-stimulated insulin secretion in ob/ob mice [33]. GW501516 did not induce insulin release in isolated islets [39], thereby suggesting that the increased insulin secretion was secondary to improved islet function. Our investigation shows that HS00098 and GW501516 played a role in maintaining blood glucose level stabilization, while it was unstable in the control group. At the same time, compared with the control group, the ascending amplitude of GW501516 and HS00098 group was significantly lower, and the ascending/declining amplitude was similar. The results suggested that GW501516 and HS00098, as PPAR $\delta$ agonists, played an important role in reducing the insulin level in obese rhesus monkeys and that the two drugs functioned in synergistic competetion with insulin. In addition, the results showed that the 2 drugs regulated the insulin level depending on the concentration of drugs, and it can be seen that HS00098 regulated the insulin level at the $1 \mathrm{mg} / \mathrm{kg}$ dosage but GW501516 was effective at the $3 \mathrm{mg} / \mathrm{kg}$ dosage. This also suggested that high levels of HS00098 $(1 \mathrm{mg} / \mathrm{kg})$ activated PPAR $\delta$ expression and then synergistically competed with insulin, thereby leading to a lower level of insulin. However, according to the previous report that PPAR $\delta$ can increase insulin sensitivity [30], HS00098 also had a similar role.

In summary, the above results suggested that the investigational drug (HS00098) can effectively reduce blood lipids and maintain the blood glucose levels of diet-induced obese rhesus monkeys depending on the dose. 


\section{ACKNOWLEDGEMENTS}

Wen Zeng, Zheng-Li Chen and An-Chun Cheng designed research; Qi-Hui Luo and Zheng-Li Chen performed research; An-Chun Cheng and Wen Zeng contributed new analytical tools and reagents; Qi-Hui Luo, Chun-Mei Zhu and Feng-Jun Bi analyzed data; Qi-Hui Luo and Zheng-Li Chen wrote the paper. Zheng-Li Chen is the Corresponding author.

\section{REFERENCES}

[1] WHO (1999) Obesity: Preventing and managing the global epidemic - Report of WHO consultation. Technical Report WHO Consultation on Obesity.

[2] Eckardstein, A. von and Assmann, G. (2000) Prevention of coronary heart disease by raising high-density lipoprotein cholesterol? Current Opinion in Lipidology, 11, 627637. doi:10.1097/00041433-200012000-00010

[3] James, P.T., Rigby, N. and Leach, R. (2004) The obesity epidemic, metabolic syndrome and future prevention strategies. European Journal of Cardiovascular Prevention and Rehabilitation, 11, 3-8. doi:10.1097/01.hjr.0000114707.27531.48

[4] Liberopoulos, E.N., Mikhailidis, D.P. and Elisaf, M.S. (2005) Diagnosis and management of the metabolic syndrome in obesity. Obesity Reviews, 6, 283-296. doi:10.1111/j.1467-789X.2005.00221.x

[5] Nammi, S., Koka, S., Chinnala, K.M. and Boini, K.M. (2004) Obesity: An overview on its current perspectives and treatment options. Nutrition Journal, 3, 3. doi:10.1186/1475-2891-3-3

[6] Korner, J. and Aronne, L.J. (2004) Pharmacological approaches to weight reduction: Therapeutic targets. Journal of Clinical Endocrinology and Metabolism, 89, 26162621. doi:10.1210/jc.2004-0341

[7] Cota, D. and Woods, S.C. (2005) The role of the endocannabinoid system in the regulation of energy homeostasis. Current Opinion in Endocrinology and Diabetes, 12, 338-351. doi:10.1097/01.med.0000178715.87999.69

[8] Evans, R.M., Barish, G.D. and Wang, Y.-X. (2004) PPARs and the complex journey to obesity," Nature Medicine, 10, 355-361. doi:10.1038/nm1025

[9] Willson, T.M., Brown, P.J., Sternbach, D.D. and Henke, B.R. (2000) The PPARs: From orphan receptors to drug discovery. Journal of Medicinal Chemistry, 43, 527-550. doi:10.1021/jm990554g

[10] Fajas, L., Fruchart, J.-C. and Auwerx, J. (1998) Transcriptional control of adipogenesis. Current Opinion in Cell Biology, 10, 165-173. doi:10.1016/S0955-0674(98)80138-5

[11] Braissant, O., Foufelle, F., Scotto, C., Dauca, M. and Wahli, W. (1996) Differential expression of peroxisome proliferator-activated receptors (PPARs): Tissue distribution of PPAR- $\alpha,-\beta$, and $-\gamma$ in the adult rat. Endocrinology, 137, 354-366. doi:10.1210/en.137.1.354

[12] Oliver, W.R., Shenk, J.L., Snaith, M.R., Russell, C.S., Plunket, K.D., Bodkin, N.L., et al. (2001) A selective peroxisome proliferator-activated receptor $\delta$ agonist promotes reverse cholesterol transport. Proceedings of the National Academy of Sciences of the United States of America, 98, 5306-5311.

[13] Wang, Y.X., Lee, C.H., Tiep, S., Yu, R.T., Ham, J.Y., Kang, H.J., et al. (2003) Peroxisome proliferator-activated receptor $\delta$ activates fat metabolism to prevent obesity. Cell, 113, 159-170. doi:10.1016/S0092-8674(03)00269-1

[14] Wang, Y.X., Zhang, C.L., Yu, R.T., Cho, H.K., Nelson, M.C., et al. (2004) Regulation of muscle fiber type and running endurance by PPAR $\delta$. PLoS Biology, 2, e294. doi:10.1371/journal.pbio.0020294

[15] Brown, P.J., D Winegar, A., Plunket, K.D., Moore, L.B., Lewis, M.C., Wilson, J.G., et al. (1999) A ureido-thioisobutyric acid (GW9578) is a subtype-selective PPAR $\alpha$ agonist with potent lipid-lowering activity. Journal of Medicinal Chemistry, 42, 3785-3788. doi:10.1021/jm9903601

[16] Yang, B.C., Brown, K.K., Chen, L.H., Carrick, K.M., Clifton, L.G., Mcnulty, J.A., et al. (2004) Serum adiponectin as a biomarker for in vivo PPAR $\gamma$ activation and PPAR $\gamma$ agonist-induced efficacy on insulin sensitization/ lipid lowering in rats. BMC Pharmacology, 4, 23. doi:10.1186/1471-2210-4-23

[17] Henke, B.R., Blanchard, S.G. and Brackeen, M.F. (1998) N-(2-benzoylphenyl)-L-tyrosine PPAR $\gamma$ agonists. 1. Discovery of a novel series of potent antihyperglycemic and antihyperlipidemic agents. Journal of Medicinal Chemistry, 41, 5020-5036. doi:10.1021/jm9804127

[18] The Ministry of Science and Technology of the People's Republic of China (2006) Guidance suggestions for the care and use of laboratory animals.

[19] OECD (1998) Test Guideline 409. Repeated dose 90-day oral toxicity study in non-rodents. OECD guidelines for the testing of chemicals, Organisation for Economic Cooperation \& Development.

[20] Okasaki, K., Funato, M., Kashima, M., Nakama, M., Inoue, K., Hiura, T., et al. (2002) Twenty-six-week repeat-dose toxicity study of a recombinant human granulocyte colony-stimulating factor derivative (Nartograstim) in cynomolgus monkeys. Society of Toxicology, 65, 246255. doi:10.1093/toxsci/65.2.246

[21] Butenhoff, J., Costa, G. and Elcombe, C. (2002) Toxicity of ammonium perfluorooctanoate in male cynomolgus monkeys after oral dosing for 6 months. Toxicological sciences, 69, 244-257. doi:10.1093/toxsci/69.1.244

[22] Rockwood, G.A., Duniho, S.M. and Briscoe, C.M. (2008) Toxicity in rhesus monkeys following administration of the 8-aminoquinoline 8-[(4-amino-1-methylbutyl)amino]5-(1-hexyloxy)-6-methoxy-4-methylquinoline (WR242511). Journal of medical toxicology, 4, 157.

[23] Buse, J.B., Klonoff, D.C., Nielsen, L.L., Guan, X., Bowlus, C.L., Holcombe, J.H., et al. (2007) Metabolic effects of two years of exenatide treatment on diabetes, obesity, and hepatic biomarkers in patients with type 2 diabetes: An interim analysis of data from the open-label, uncontrolled extension of three double-blind, placebocontrolled trials. Clinical Therapeutics, 29, 139-153. 
doi:10.1016/j.clinthera.2007.01.015

[24] Zhang, F., Lavan, B. and Gregoire, F.M. (2004) Peroxisome proliferator-activated receptors as attractive antiobesity targets. Drug News and Perspectives, 17, 661669. doi:10.1358/dnp.2004.17.10.873918

[25] Fredenrich, A. and Grimaldi, P.A. (2005) PPAR $\delta$ : An uncompletely known nuclear receptor. Diabetes and $\mathrm{Me-}$ tabolism, 31, 23-27. doi:10.1016/S1262-3636(07)70162-3

[26] Luquet, S., Lopez-Soriano, J., Holst, D., Gaudel, C., Chantal, J.P., Alexandre, F., et al. (2004) Roles of peroxisome proliferator-activated receptor $\delta$ (PPAR $\delta$ ) in the control of fatty acid catabolism. A new target for the treatment of metabolic syndrome. Biochimie, 86, 833-837. doi:10.1016/j.biochi.2004.09.024

[27] Shin, H.D., Park, B.L., Kim, L.H., Jung, H.S., Cho, Y.M., Moon, M.K., et al. (2004) Genetic polymorphisms in peroxisome proliferator-activated receptor $\delta$ associated with obesity. Diabetes, 53, 847-851. doi:10.2337/diabetes.53.3.847

[28] Muurling, M., Mensink, R.P., Pijl, H., Romijn, J.A., Havekes, L.M. and Voshol, P.J. (2003) Rosiglitazone improves muscle insulin sensitivity, irrespective of increased triglyceride content, in ob/ob mice. Metabolism, 52, 1078-1083. doi:10.1016/S0026-0495(03)00109-4

[29] Leibowitz, M.D., Fievet, C., Hennuyer, N., et al. (2000) Activation of PPAR $\delta$ alters lipid metabolism in $\mathrm{db} / \mathrm{db}$ mice. FEBS Letters, 473, 333-336. doi:10.1016/S0014-5793(00)01554-4

[30] Lee, C.H., Olson, P., Hevener, A., Mehl, I., Chong, L.W., Olefsky, J.M., et al. (2006) PPAR $\delta$ regulates glucose metabolism and insulin sensitivity. Proceedings of the National Academy of Sciences of the United States of America, 103, 3444-3449. doi:10.1073/pnas.0511253103

[31] Graham, T.L., Mookherjee, C., Suckling, K.E. and Patel, L. (2005) The PPAR delta agonist GW0742X reduces atherosclerosis in $\operatorname{LDLR}(-/-)$ mice. Atherosclerosis, 181, 29-37. doi:10.1016/j.atherosclerosis.2004.12.028

[32] Kang, K., Hatano, B. and Lee, C.H. (2007) PPAR delta agonists and metabolic diseases. Current Atherosclerosis Reports, 9, 72-77. doi:10.1007/BF02693931

[33] Tanaka, T. (2003) Activation of peroxisome proliferatoractivated receptor delta induces fatty acid betaoxidation in skeletal muscle and attenuates metabolic syndrome. Proceedings of the National Academy of Sciences, 100 15924-15929. doi:10.1073/pnas.0306981100

[34] Lichtenstein, A.H., Kennedy, E., Barrier, P., Ernst, N.D., Grundy, S.M., Leveille, G.A., et al. (1998) Dietary fat consumption and health. Nutrition Reviews, 56, S3-S28. doi:10.1111/j.1753-4887.1998.tb01728.x

[35] Grundy, S.M. (1998) Effects of crystalline nicotinic acid-induced hepatic dysfunction on serum low-density lipoprotein cholesterol and lecithin cholesteryl acyl transferase. American Journal of Cardiology, 81, 805-807.

[36] Ginsberg, H.N. (2000) Insulin resistance and cardiovascular disease. The Journal of Clinical Investigation, 106, 453-458. doi:10.1172/JCI10762

[37] Marais, A.D. (2000) Therapeutic modulation of lowdensity lipoprotein size. Current Opinion in Lipidology, 2000, 11, 597-602. doi:10.1097/00041433-200012000-00005

[38] Tall, A.R. and Wang, N. (2000) Tangier disease as a test of the reverse cholesterol transport hypothesis. Journal of Clinical Investigation, 106, 1205-1207. doi:10.1172/JCI11538

[39] Kharroubi, I., Lee, C.H., Hekerman, P., Darville, M.I., Evans, R.M., Eizirik, D.L., et al. (2006) BCL-6: A possible missing link for anti-inflammatory PPAR-delta signalling in pancreatic beta cells. Diabetologia, 49, 23502358. doi:10.1007/s00125-006-0366-5 